\title{
Sinergitas Koperasi Dan Bum Desa Dalam Mengembangkan Produk Gula Kelapa Desa Kalak Kecamatan Donorojo Kabupaten Pacitan
}

\author{
Smita Catur Sudyantara \\ Ekonomi, Universitas Merdeka Ponorogo, Jl. Pacar No.35, Tonatan, Ponorogo, 63418 \\ E-mail: smita.csdyntr@gmail.com
}

\begin{abstract}
Pengembangan potensi desa menjadi prioritas utama dalam rangka meningkatkan perekonomian desa melalui perhatian terhadap produksi produk unggulan yang dihasilkan masyarakat lokal dimana memiliki nilai ekonomis dan menggerakkan ekonomi masyarakat. Desa Kalak Kecamatan Donorojo adalah salah satu desa yang memiliki potensi produk unggulan yang dapat dikembangkan yaitu gula kelapa meliputi gula cetak dan gula semut. Banyak pelaku umkm yang memproduksi gula kelapa merupakan anggota koperasi Himpulo. Koperasi Himpulo membantu meningkatkan pendapatan anggotanya dengan membeli produk hasil produksi gula kelapa, mengemas dan memasarkannya. Selain itu juga di Desa Kalak telah terbentuk dan berjalan BUM desa Rejo Raharjo yang berperan dalam pengelolaan unit bisnis yang bisa dijalankan sesuai dengan. Sinergitas koperasi Himpulo dan Bumdes Rejo Raharjo adalah bentuk kerjasama ditingkat desa untuk meningkatkan produktifitas dan kualitas produk gula kelapa. Dalam sinergitas tersebut dikuatkan dengan perjanjian kerjama sama untuk menjalankan bisnis atau usaha yang fokus pada produk gula kelapa. Adapun skema sinergitas yang dilakukan adalah dengan model bisnis melalui penyertaan modal yang diberikan BUMdes rejo raharjo kepada koperasi Himpulo. Kedua lembaga tersebu memiliki komitment menjalankan bisnis secara bersama untuk dapat mengembangkan produk gula kelapa menjadi lebih baik dan mampu meningkatkan pendapatan pelaku umkm yang terlibat. Sebab masih terdapat kendala yang dihadapi yaitu peningkatan kualitas produk, kemasaran dan pemasaran gula kelapa. Tujuan penelitian ini adalah untuk mendiskripsikan implementasi sinergitas koperasi Himpulo dan BUM (Badan Usaha Milik) desa Rejo Raharjo dengan menggunakan pendekatan penelitian diskriptif kualitatif. Kesimpulan dari penelitian ini yaitu pada kenyataannya telah terjalin sinergitas koperasi Himpulo dan BUM desa Rejo Raharjo untuk mengembangkan produk gula kelapa utamanya gula semut. Pada tahap awal belum menunjukkan berbagai perkembangan yang signifikan terhadap kenaikan pendapatan anggota koperasi himpulo sebab masih fokus pada pengembangan produk.
\end{abstract}

Keywords — : sinergitas koperasi dan Bumdesa; bumdesa; koperasi; sinergitas.

\section{PENDAHULUAN}

Isu pengembangan desa memang selalu menjadi perhatian pemerintah pusat dan daerah demi untuk menjamin terlaksananya pemerataan pembangunan diberbagai pelosok wilayah indonesia. Pembangunan yang merata merupakan prioritas utama dalam rangka mewujudkan masyarakat adil dan makmur sesuai dengan cita-cita yang diamanatkan Undang-Undang Dasar 1945 . Perhatian pemerintah yang ingin membangun ekonomi dari desa memberikan berbagai dampak pada peningkatan kesejahteraan yang menekankan pada pengembangan desa. Eksplorasi potensi desa terus digiatkan untuk menumbuhkan berbagai peluang usaha yang dapat dijalankan oleh banyak pelaku usaha yang berdomisili dilokasi tersebut. Berkembangnya desa akan mendorong pada meningkatnya ekonomi dan kesejahteraan warga setempat sehingga diharapkan mampu mengurangi kemiskinan yang sering terjadi didesa.

Kebijakan pemerintah untuk membangun desa sudah dapat direalisasikan dengan adanya Undang-Undang No 6 tahun 2014, desa yang menjamin dan memberikan wewenang sepenuhnya kepada desa melalui dana desa. Meningkatnya jumlah besaran alokasi dana desa setiap tahunnya akan memberikan dukungan yang berkelanjutan terhadap pembangunan semua bidang terutama bidang ekonomi. Desa memiliki tanggungjawab dalam mengembangkan berbagai potensi ekonomi lokal dan mengelolanya demi meningkatkan kesejahteraan masyarakatnya. Sektor ekonomi merupakan tumpuan utama untuk bisa memberdayakan masyarakat dalam menghasilkan bermacam-macam produk dan jasa yang berbahan baku lokal. Selain itu juga dapat mendorong keterlibatan masyarakat sekitar sebagai pelaku umkm untuk berproduksi sehingga mampu menumbuhkan jiwa kewirausahaan serta meningkatkan pendapatannya.

Dalam kerangka pengembangan desa dibidang ekonomi dan sesuai dengan pelaksanaan undang-undang desa maka desa memiliki badan usaha milik desa yang disebut dengan BUM desa. Adapun BUM (Badan Usaha Milik) desa tersebut mendapatkan alokasi pembiayaan yang dapat bersumber dari APBDesa. Desa harus mampu mengembangkan dan meningkatkan pendapatan desa melalui pengelolaan BUM desa secara profesional. Dalam membentuk dan menjalankan BUM desa maka dapat dipilih pengurus yang berasal dari warga masyarakat setempat untuk menjadi bagian dari pihak manajemen BUM desa. Berbagai unit usaha yang akan dikelola dan dikembangkan oleh BUM desa seharusnya dapat disesuaikan dengan potensi yang dimiliki desa.

Kondisi ekonomi desa memang banyak ditopang oleh berbagai sektor usaha terutama yang melibatkan para pelaku umkm. Kegiatan produksi usaha yang dilakukan oleh mereka membutuhkan sentuhan dan perhatian dari desa melalui BUM desa. Oleh karenanya BUM desa dapat menjadi badan usaha yang mampu mengoptimalkan dan menjembatani semua kegiatan usaha 
berbasis sumber daya lokal. Unit usaha yang dijalankan dapat memberdayakan masyarakat untuk bisa menghasilkan berbagai produk unggulan lokal yang dikemas dan dipasarkan oleh BUM desa. Selain itu juga dapat membangun bisnis atau usaha yang berorientasi pada pasar untuk berbagai bidang usaha atau sektor jasa lain seperti pariwisata, pertanian dan lainnya.

UMKM didesa membutuhkan campur tangan dari berbagai pihak agar memberikan dorongan untuk meningkatkan kesejahteraan mereka. Kebanyakan dari mereka adalah pelaku ekonomi yang membuat atau menghasilkan produk yang diolah dari bahan-bahan lokal atau memanfaatkan potensi yang ada. Kegiatan produksi yang dilakukan menjadi sumber pendapatan utama untuk menopang ekonomi keluarga. Walaupun produk yang dihasilkan terkadang belum sesuai dengan standar dan tidak bisa bersaing. Selain itu banyak kendala usaha yang sering dihadapi dalam menjalankan usaha tersebut seperti pemasaran, permodalan dan packaging.

Pada kenyataannya telah terbentuk BUM desa pada tiap desa diseluruh kabupaten di propinsi jawa timur termasuk Kabupaten Pacitan. Terbentuknya BUM desa dikuatkan dengan penetapan lembaga dan susunan pengurusnya melalui surat keputusan kepala desa. Walaupun BUM desa telah ditetapkan dan mampu menjalankan tugasnya namun perlu diperhatikan bahwa ada lembaga lain dibidang ekonomi yang tentunya juga sudah lama berdiri pada masing-masing desa yaitu koperasi. Koperasi yang bisa dipastikan ada diseluruh desa di Kabupaten Pacitan adalah koperasi wanita yang melibatkan kaum perempuan terutama ibu-ibu rumah tangga sebagai anggotanya dan bentuk koperasi lainnya. Kegiatan berkoperasi tentunya juga memberikan ruang dalam pengembangan ekonomi didesa. Kedua lembaga yang berada didesa tersebut yaitu BUM desa dan Koperasi memiliki peran dan fungsi masing-masing tetapi tidak menutup kemungkinan untuk keduanya saling sinergi dan kerjasama dalam membangun ekonomi desa.

Koperasi dan BUM desa pada dasarnya tetap akan menjalankan tugas sesuai dengan tujuan yang ingin dicapai masingmasing. Namun keberadaan kedua lembaga tersebut pada suatu desa akan memberikan kontribusi yang besar terhadap peningkatan ekonomi masyarakat. Apabila keduanya dapat bekerjasama untuk membangun usaha yang saling menguntungkan tentunya juga akan lebih bermanfaat bagi masyarakat. Menyatukan visi untuk bekerja dijalur yang sama dalam pengembangan potensi desa akan mendorong kemajuan desa. Skema ataupun pola kerjasama dapat diwujudkan dengan membentuk atau membuat unit usaha atau fokus pada pengembangan produk unggulan lokal dari hulu sampai hilir.

Sejalan dengan keberadaan BUM desa dan Koperasi yang ada didesa, ditingkat pusat telah terjadi kesepakatan atau MOU antara Kementrian Desa, Pembangunan Daerah Tertinggal dan Transmigrasi Republik Indonesia dengan Kementrian Koperasi dan Usaha Kecil dan Menengah Republik Indonesia Tentang Pembangunan dan Pemberdayaan Ekonomi Masyarakat Desa, Daerah Tertinggal dan Transmigrasi Melalui Sinergi Koperasi dan Badan Usaha Milik Desa No : 12 /M.DPDTT/KB/IX/2016 dan No : 14 /KB/M.KUKM/IX/2016. Berdasarkan hal itu maka di Kabupaten Pacitan telah merealisasikan melalui forum sinergitas koperasi dan BUM desa yang anggota terdiri dari lintas sektor dimana beberapa anggotanya meliputi Dinas Koperasi dan Usaha Mikro dan Dinas Pemerintahan Desa mendorong pada kerjasama antara koperasi dan BUM desa. Salah satu desa yang dapat melakukan kerjasama itu adalah Desa Kalak Kecamatan Donorojo. Bentuk kerjasama diatur melalui perjanjian kerjasama antara koperasi Himpulo dan BUM desa Rejo Raharjo. Dengan kerjasama tersebut dapat memberikan bukti dan penguatan terhadap implementasi wujud sinergitas koperasi dan BUM desa yang dapat terlaksana dari kebutuhan untuk memajukan produk unggulan lokal.

Koperasi Himpulo Desa Kalak merupakan koperasi yang bergerak dalam bidang pembiayaan dan pemberdayaan masyarakat yang anggotanya adalah para pengrajin nira. Para pengrajin itu memproduksi nira menjadi gula kelapa yang dapat berupa gula cetak dan gula semut. Produk yang dihasilkan merupakan upaya pengolahan dan pemanfaatan potensi lokal Desa Kalak yang cukup terkenal yaitu gula kelapa. Koperasi Himpulo berperan dalam mengelola dan menampung semua produk yang dihasilkan oleh anggotanya kemudian dipasarkan ke berbagai lokasi sekitar dan luar Desa Kalak. Sedangkan BUM desa Rejo Raharjo berusaha untuk ambil bagian mendukung pengembangan usaha produk gula kelapa melalui kesepakatan kerjasama dengan Koperasi Himpulo dalam skema penyertaan modal. Pola kerjasama tersebut diharapkan akan lebih mampu untuk mendongkrak peningkatan pendapatan dan produksi gula kelapa Desa Kalak.

\section{KAJIAN LITERATUR}

\section{A. Bum Desa}

Fokus BUM desa pada pengembangan potensi desa merupakan sebuah upaya yang strategis untuk dilaksanakan dalam mendukung pembangunan desa dibidang ekonomi. Banyak potensi desa yang dapat dikelola dan dikembangkan untuk kepentingan desa dan tetap melibatkan pemberdayaan masyarakat setempat. Melalui BUM desa diharapkan banyak cabang usaha yang bisa dijalankan dengan menggunakan semua sumber daya lokal yang ada. Disamping itu, BUM desa harus mampu menjalankan bisnis yang maju dan modern agar dapat terus eksis dan meningkatkan daya saingnya. Dengan usaha atau bisnis tersebut pada dasarnya akan memberikan kontribusi pendapatan pada desa yang akan dimanfaatkan bagi seluruh warga desa.

Mengembangkan bisnis berbasis desa memang menjadi tanggungjawab yang harus dilakukan oleh badan usaha desa sebagai ujung tombak pelaksana bisnis didesa. Semua potensi bisnis yang memiliki prospek bagus harus mampu dijalankan dan dikembangkan untuk mencapai keuntungan yang diinginkan. Semua bidang usaha yang sesuai dengan karakteristik desa dan sumber daya lokal wajib dikelola dengan baik agar mendatangkan pemasukan. Target pemasukan yang diharapkan sebenarnya akan membentuk bisnis itu sendiri menjadi bisnis yang benar-benar menguntungkan dan dapat terus eksis sesuai dengan kebutuhan pasar. Dalam manajemen pengelolaannya juga harus didukung oleh sumber daya manusia yang memang 
Website : http://ekomaks.unmermadiun.ac.id/index.php/ekomaks

berkompeten dibidangnya. Untuk pembiayaan usaha BUM desa memiliki kelebihan yaitu mendapatkan anggaran dari APBDes atau Anggaran pendapatan dan belanja desa.

Menurut Permendesa No 4 Tahun 2015 tentang Pendirian, Pengurusan Dan Pengelolaan, Dan Pembubaran Badan Usaha Milik Desa pengertian BUM desa adalah adalah badan usaha yang seluruh atau sebagian besar modalnya dimiliki oleh Desa melalui penyertaan secara langsung yang berasal dari kekayaan Desa yang dipisahkan guna mengelola aset, jasa pelayanan, dan usaha lainnya untuk sebesar-besarnya kesejahteraan masyarakat Desa. Berdasarkan hal itu menunjukkan bahwa setiap desa bisa menjalankan sebuah badan usaha yang didukung penuh dalam anggaran dana desa. Sebagai sebuah badan usaha yang dimiliki desa tentunya harus mampu merencanakan dan mengelola semua usaha atau bisnis yang akan dijalankan desa. Pemilihan bisnis yang menguntungkan akan berdampak baik pada peningkatan pendapatan dari usaha yang dikelola. Tugas yang paling berat yaitu mewujudkan suatu pengelolaan badan usaha yang profesional dan berkelanjutan. Dengan orientasi pada kualitas layanan yang diberikan maka akan membentuk kekuatan usaha yang mendorong pada kemampuan bersaing dan memiliki daya saing.

Dalam dunia usaha memang tidak bisa dipungkiri adanya persaingan baik dengan usaha sejenis atau BUM desa diwilayah terdekat. Menjalankan BUM desa membutuhkan banyak sumberdaya yang harus mampu dikelola dengan baik baik itu sumber daya manusia, sumber daya bisnis yang bisa digerakkan dan sumber daya lainnya yang mendukung. Bertahan diiklim bisnis diera sekarang menjadi cambuk untuk menciptakan tata kelola usaha BUM desa yang bisa berkembang dan maju. Membangun strategi manajemen BUM desa merupakan tugas desa yang didelegasikan kepada pengurus BUM desa untuk mewujudkannya. Adapun dalam struktur organisasi BUM desa harus diisi oleh orang-orang yang memiliki kompeten dan tanggungjawab tinggi untuk mengembangkan desanya. Kepentingan jangka panjang dan jangka pendek harus dapat terencanakan dan terealisasikan dengan baik sesuai anggaran yang disediakan. Selain itu, menjalin koordinasi harus terus dilakukan oleh pengurus dengan kepala desa sebagai wakil masyarakat didesa dan sebagai kepala pemerintahan desa untuk menyeleraskan dengan kebutuhan masyarakat dalam bidang ekonomi.

\section{B. Koperasi}

Koperasi merupakan salah satu gerakan ekonomi masyarakat yang menjunjung tinggi semangat kebersamaan dan kekeluargaan untuk peningkatan kesejahteraan bersama. Tujuan yang sama dari para anggotanya untuk membangun komitmen yang kuat harus menjadi dasar untuk mencapai cita-cita yang diinginkan. Pengurus koperasi sebagai representasi suara anggota memang menjadi penggerak dalam pencapaian keberhasilan koperasi. Dengan berkoperasi menjadi solusi untuk mengatasi permasalahan ekonomi yang merupakan salah satu aspek yang berpengaruh terhadap kualitas kehidupan masyarakat. Kekuatan yang dibangun sesuai dengan pemikiran bersama tentunya akan memberikan daya dorong yang optimal demi kemajuan koperasi.

Dalam menjalankan sebuah koperasi kepentingan anggota memang memiliki prioritas yang utama untuk didahulukan. Hal tersebut dapat terwujud melalui pengelolaan koperasi yang baik sesuai dengan jenis koperasi yang dijalankan. Pada dasarnya koperasi memang terdiri dari berbagai jenis koperasi sesuai dengan jenis usaha yang diinginkan. Semua aturan, tata kelola dan tata laksana koperasi akan tertuang dengan jelas melalui anggaran dasar dan anggaran rumah tangga yang dibuat sesuai dengan kesepakatan bersama. Maka hal tersebut menjadi pedoman dalam melaksanakan semua kegaiatan operasional koperasi dan tidak boleh keluar dari jalur yang sudah ditentukan.

Tantangan dan kendala juga akan terus membayangi dalam setiap kegiatan usaha yang dilakukan oleh koperasi. Perlu sebuah antisipasi dan kesiapan yang harus dipersiapkan secara matang melalui perencanaan yang baik terutama untuk koperasi dan usaha yang dijalankan. Manajemen merupakan kunci utama untuk bisa memajukan unit usaha dan koperasi untuk mencapai semua visi yang ditetapkan. Usaha koperasi dapat terbagi menjadi usaha utama, usaha pendukung dan usaha tambahan. Adapun yang penting untuk diperhatikan adalah selalu melakukan evaluasi yang disampaikan dalam rapat anggota untuk mencari solusi dan kebijakan yang tepat untuk kedepannya.

Pengertian koperasi menurut Undang-Undang No. 25 tahun 1992 Pasal 1 adalah badan usaha yang beranggotakan orang seorang atau badan hukum koperasi dengan berlandaskan kegiatan pada prinsip koperasi sekaligus sebagai gerakan ekonomi rakyat yang berdasar atas azas kekeluargaan. Pada dasarnya bentuk badan usaha yang memiliki legalitas yang diakui negara selain PT dan CV adalah koperasi sehingga memberikan kemudahan bagi masyarakat untuk menjalankan usaha sesuai tujuan yang diinginkan bersama. Dalam mekanisme pembentukannya cukup mudah sebab hanya minimal anggota 20 orang sudah dapat mendirikan koperasi dengan memperhatikan berbagai syarat dan ketentuan yang berlaku. Semua anggota memiliki hak dan kewajiban yang sama dalam mendukung dan memajukan koperasi. Adapun menurut Hendar (2002:117), nilai-nilai etis merupakan perekat yang harus dimiliki oleh setiap anggota koperasi yang meliputi: (1) Kejujuran, (2) Kerterbukaan, (3)Tanggung jawab sosial, (4) Kepedulian terhadap orang lain. Disamping itu juga koperasi dijalankan atas asas kekeluargaan dimana semua keputusan harus melalui musyawarah mufakat dan hasil keputusan tidak bertolak belakang terhadap kepentingan anggota.

Perkembangan ekonomi dan perbedaan tingkat kesejahteraan masyarakat sering menimbulkan berbagai kesenjangan. Dalam kondisi tersebut memang membutuhkan solusi bagi masyarakat melalui gerakan berkoperasi yang menyusun dan membangun ekonomi dari bawah. Kekuatan yang dikumpulkan dalam sebuah kesepakatan dan komitmen dapat mendorong pada pembentukan berbagai unit usaha yang bisa dijalankan oleh koperasi. Dengan rasa memiliki dari anggota maka akan lebih mendorong mereka untuk memberikan kontribusi pada pemikiran dan pengembangan usaha yang dapat menguntungkan 
Website : http://ekomaks.unmermadiun.ac.id/index.php/ekomaks

koperasi. Oleh karenanya koperasi di Indonesia dapat berperan serta dalam peningkatan kesejahteraan masyarakat sehingga menjadi soko guru perekonomian maupun sebagai tulang punggung rakyat (Bernhard Limbong, 2010:33).

Dalam koperasi keputusan tertinggi adalah melalui rapat anggota. Pengurus hanya melaksanakan semua keputusan yang sudah disepakati dan menjalankan semua kegiatan operasional koperasi sesuai aturan yang sudah ditetapkan. Mengedepan nilai-nilai dalam berkoperasi akan sangat membantu pengurus yang pada dasarnya bertanggungjawab pada anggota, dimana anggota memiliki hak untuk bertanya langsung tentang kemajuan koperasi atau melalui pengawas koperasi. Menurut Andjar Pachta.W (2008;88) bahwa nilai koperasi dapat dipandang sebagai nilai dasar (fundamental) dan nilai-nilai etis yang mencakup: (1) Menolong diri sendiri, (2)Tanggung jawab sendiri, (3) Demokrasi, (4) Persamaan, (5) Keadilan dan (6) Solidaritas. Kesemua nilai diatas memberikan gambaran mengenai pentingnya kepedulian antar sesama anggota dan kepada pengurus untuk saling memahami peran dan tanggungjawab masing-masing serta kepercayaan untuk mengembangkan koperasi.

\section{III.METODE PENELITIAN}

Dalam penelitian ini menggunakan metode diskriptif kualitatif untuk mendiskripsikan secara kualitatif berdasarkan hasil kegiatan lapangan baik itu pengamatan, interview dan kegiatan lainnya untuk mendukung hasil. Menurut Moloeng (2005:248) dalam penerapan penelitian kualitatif menggunakan metode analisis data meliputi yaitu :

1. Mencatat yang menghasilkan catatan lapangan dengan hal itu diberi kode agar sumber datanya dapat tetap ditelusuri.

2. Mengumpulkan, memilah-milah, mengklasifikasikan, mensintesiskan, membuat ikhtisar dan membuat indeksnya.

3. Berpikir dengan jalan membuat agar kategori data itu mempunyai makna, mencari dan menemukan pola hubunganhubungan dan membuat temuan-temuan umum.

\section{IV.HASIL DAN PEMBAHASAN}

Kerjasama bisnis atau usaha antara BUM desa dan Koperasi merupakan sebuah implementasi dari sinegitas antar kedua lembaga tersebut. Dengan begitu akan terbentuk kekuatan bisnis baru di desa dan saling menguntungkan untuk keduanya dan kepentingan masyarakat. Disamping itu, visi yang sama untuk berjalan bersama akan lebih mampu untuk mendorong pada pengembangan produk unggulan yang merupakan potensi desa. Peningkatan kualitas produk akan lebih menjadikan nilai jual produk itu lebih tinggi dari sebelumnya. Oleh karena juga akan berdampak pada aspek pasar dan kemampuan bersaing dengan berbagai produk yang sudah ada.

Desa Kalak merupakan salah satu desa di Kecamatan Donorojo yang telah terjalin sinergitas koperasi dan BUMDES yaitu koperasi Himpulo dan BUMDES Rejo Raharjo. Dasar pelaksanaan kesepakatan itu adalah menjalin sinergi dan berbagi peran dalam memajukan potensi produk lokal desa kalak yang menjadi salah satu unggulan. Adapun produk yang dikembangkan adalah gula semut dan gula batok yang merupakan hasil olahan dari gula kelapa. Memang yang menjadi potensi desa kalak yaitu gula kelapa yang menjadi sumber pendapatan bagi para pelaku umkm setempat. Sebagian dari mereka mengolah dan menjual produk tersebut untuk memperoleh pendapatan setiap harinya.

Koperasi himpolo yang merupakan koperasi yang beranggotakan para ibu-ibu rumah tangga yang juga sebagai pelaku umkm gula kelapa. Koperasi ini berdiri pada tahun 2016 dengan nama Himpulo Karya Kita dan menjalankan operasional kegiatannya pada usaha simpan pinjam. Walaupun seperti itu anggotanya dapat dikatakan sebagai kumpulan orang-orang yang produktif. Mereka memproduksi gula kelapa menjadi berbagai produk yang memiliki nilai jual dan sebagai penopang kebutuhan seharihari. Peran strategis yang dimiliki koperasi himpulo yaitu mengelola dan memasarkan produk gula kelapa tersebut untuk meningkatkan kesejahteraan anggotanya.

Untuk mendukung kegiatan produksi gula kelapa yang dilakukan oleh anggotanya, koperasi himpulo menampung produk anggota kemudian dikemas dan dipasarkan. Produk gula kelapa yang sudah menjadi gula batok dan gula kelapa dibeli oleh koperasi himpulo dengan harga yang sesuai. Kemudian dikemas dengan kemasan yang baik dan dipasarkan ke berbagai tempat. Dalam menghasilkan kualitas produk yang bagus koperasi himpulo juga melakukan pengawasan dan pembinaan kepada anggota dalam memproduksi nira sebagai bahan bahan dasar gula kelapa. Hal tersebut memberikan dampak ekonomi yan gcukup siginifikan terhadap pendapatan anggotanya untuk memenuhi kebutuhan sehari-hari.

Koperasi Himpulo memiliki anggota koperasi sebanyak 38 orang dimana yang menjadi produsen gula kelapa sejumlah 15 orang. Adapun masing-masing produsen terbagi menjadi 28 orang produsen gula cetak dan 1 orang produsen gula semut yang terlibat. Jumlah tersebut dihitung dari keterlibatan beberapa orang yang memiliki hubungan dalam proses produksi gula kelapa. Anggota koperasi yang memiliki pohon kelapa dalam memperoleh nira sabagai bahan gula merah tidak dikerjakan sendiri namun menjalin kerjasama dengan beberapa orang yang masih memiliki hubungan famili atau tetangganya. Mereka menjalin kerjasama dengan tetangga atau yang masih berhubungan famili untuk mengambil nira diatas pohon kelapa. Skema yang dilakukan dalam proses kerjasama ini adalah bagi hasil dengan penghitungan sehari untuk pemilik dan sehari berikutnya untuk yang diajak bekerjasama dan berulang.

Anggota koperasi himpulo meliputi kelompok perempuan didua dusun di desa kalak yaitu dusun klepu dan pulo. Mereka rutin mengadakan pertemuan dalam rangka membahas kegiatan usaha yang dijalankan terutama produksi gula kelapa. Selain itu anggota koperasi yang memproduksi gula kelapa memiliki komitmen yang baik untuk secara bersama-sama menyetorkan atau menjual produknya ke koperasi. Pasokan dari pengrajin kepada koperasi disesuaikan dengan kapasitas produksi yang dimiliki 
masing-masing. Adapun semua produk tersebut dibeli dengan harga yang layak oleh koperasi himpulo. Namun banyak kendala yang dihadapi oleh pelaku gula kelapa yaitu masalah pemasaran dan kemasan.

BUM desa Rejo Raharjo Desa Kalak mulai beroperasi atau berjalan efektif pada awal tahun 2019. Dalam perjalanannya memang mengalami berbagai masalah mulai dari aspek kelembagaan sampai pada kegiatan bisnis inti yang akan dilakukan. Namun sebenarnya BUM desa tersebut sudah mendapatkan alokasi anggaran dari dana desa yang bisa digunakan untuk berkegiatan. Adapun susunan pengurus untuk mengelola lembaga itu juga sudah terbentuk dan diperkuat dengan surat keputusan kepala desa. Dengan dukungan dana desa dapat sepenuhnya mendorong pengembangan BUM desa dan berorientasi pada pelaksanaan bisnis yang bisa mengangkat produk unggulan desa.

Dalam proses terjalinnya kerjasama melalui sinergitas koperasi dan BUMDes tidak terlepas dari dorongan dan motivasi berbagai pihak. Walaupun pada dasarnya dua lembaga yang menjalankan kegaiatan usaha atau bisnis bisa saja menjalin kerjasama jika saling menguntungkan. Kesepakatan dan komitmen yang akan dibangun tentunya bukan sebuah paksaan dan terdapat faktor kepentingan yang dapat merugikan kedua belah pihak dikemudian hari. Akan tetapi didasari pada sebuah visi bersama untuk membangun desa dan meningkatkan ekonomi masyarakat dengan melibatkan kelompok masyarakat miskin dan perempuan. Selain itu pentingnya peran berbagai pihak untuk mendorong sinergi kedua lembaga tersebut. Adapun pihak terlibat adalah dinas koperasi dan usaha mikro kabupaten pacitan, dinas pemerintah desa kabupaten pacitan dan pihak lembaga pemberdayaan masyarakat.

Pentingnya peran serta dari berbagai pihak terutama pemerintah untuk mewujudkan sinergi antara koperasi dan BUM desa Rejo Raharjo sebagai bentuk kebijakan dalam bidang ekonomi. Campur tangan pemerintah merupakan sebuah kewajiban dalam rangka meningkatkan perekonomian desa melalui peningkatan fungsi keberadaan koperasi dan BUM desa. Mempertemukan kedua lembaga itu untuk tujuan pengembangan ekonomi menjadi salah satu solusi untuk meningkatkan potensi desa yang berorientasi pada peningkatan kesejahteraan masyarakat. Akan tetapi perlu juga dukungan dari pemerintah dan pihak lainnya untuk menjadikan produk unggulan desa memiliki kualitas dan pemasaran yang baik. Hal itu akan mendorong pada produktivitas umkm gula kelapa yang lebih baik terutama produk gula semut sebab memiliki nilai ekonomi yang lebih tinggi.

Cara membangun kerjasama antara koperasi dan BUMDES memang bukanlah hal yang mudah perlu sebuah konsep perencanaan yang baik melalui penyamaan visi antar kedua lembaga tersebut. Peran pihak luar juga diperlukan untuk mendukung proses sinergi antara koperasi dan BUM desa. Walaupun terdapat dasar MOU ditingkat kementrian yaitu antara Kementrian Koperasi Republik Indonesia dengan Kementrian Desa, daerah Tertinggal dan Transmigrasi Republik Indonesia yang memberikan acuan dan pedoman untuk dapat dilaksanakan ditingkat bawah. Tujuannya yaitu memberikan ruang dan keleluasaan untuk menjalin kerjasama mengembangkan bisnis di desa. Disamping itu BUM desa memiliki kekuatan modal yang cukup besar sebab mendapatkan porsi dari dana desa dimana dana desa menjadi prioritas kebijakan pembangunan desa yang nilainya semakin besar setiap tahunnya.

Fokus pengembangan usaha dalam kerjasama BUM desa dan koperasi Himpolo adalah pada pengembangan produk gula semut dan gula cetak. Untuk menghasilkan kualitas produk yang lebih baik lagi, para pelaku umkm gula kelapa mendapatkan pendampingan dan pelatihan baik dari pemerintah maupun pihak lainnya. Adapun pendampingan dan pelatihan dilakukan oleh Dinas koperasi dan usaha mikro Kabupaten Pacitan serta KOMPAK. Kolaborasi antara pemerintah dan lembaga pemberdayaan masyarakat tersebut mampu memberikan dukungan dalam mengawal kemajuan pelaksanaan sinergitas koperasi dan BUM desa. Pengembangan yang diharapkan tidak hanya pada peningkatan kualitas produk tetapi juga pada model bisnis dan pemasaran yang dilakukan sehingga berdampak siginifikan terhadap pendapatan yang diperoleh oleh umkm gula kelapa.

Model sinergi yang dilakukan oleh kedua lembaga diatas yaitu dengan skema penyertaan modal yang dilakukan oleh BUM desa Rejo Raharjo kepada Koperasi Himpulo. Sesuai dengan kesepakatan yang sudah ditandatangani bersama yaitu BUM desa memberikan modal untuk dikelola oleh koperasi Himpulo dalam memproduksi gula semut dan gula cetak. Semua perencanaan pembiayaan menjadi tanggungjawab koperasi himpulo sampai pada produk jadi dan dipasarkan. Kendala yang dihadapi produk koperasi himpulo sebelumnya adalah belum memiliki nama untuk merek produk dan kemasan yang belum bagus. Selain itu dari aspek pemasaran juga masih mengalami masalah karena produk gula kelapa masih menjangkau lokasi sekitar dan beberapa pasar di kecamatan donorojo.

Meningkatkan kualitas produk merupakan suatu rangkaian yang tidak terpisahkan dan harus dimulai dari penggunaan bahan baku, proses produksi dan sampai pada hasil produknya. Maka hal tersebut memerlukan pelatihan meliputi kualitas pengambilan nira yang bersih dan proses produksi dimana difasilitasi dan didampingi oleh KOMPAK. Produk gula kelapa yang bermutu adalah yang tidak mengandung bahan campuran kimia dan diproses secara higienis. Walaupun standar operasional presedur dalam rangkaian proses produksi gula kelapa memang belum sepenuhnya dimiliki tetapi semuanya memperhatikan aspek higienitas baik dari tempat untuk mengambil nira, pohon nira dan proses perebusan serta pengeringan. Peran koperasi himpulo tersebut menyelamatkan umkm dari praktek-praktek tengkulak yang hanya membeli produk dengan harga yang murah.

Meskipun sudah mulai menjalankan sinergi dengan model atau skema yang sudah diatur melalui perjanjian kerjasama tanggal 28 Juli 2019 tetapi BUM desa belum memberikan sepenuhnya penyertaan modal senilai Rp. 5.000.000. Kedua belah pihak masih mengalami banyak kendala untuk mengembangkan produk gula kelapa untuk sesuai dengan target yang diharapkan. Prioritas yang dilakukan adalah meningkatkan kualitas produk, pengetahuan dan pemahaman umkm gula kelapa mengenai produksi gula kelapa yang higienis serta manajemen bisnisnya. Solusi yang dilakukan karena belum memiliki nama atau merek produk gula kelapa maka disepakati produk gula kelapa baik itu gula cetak dan gula semut bermerk himpulo. Fokus 
Website : http://ekomaks.unmermadiun.ac.id/index.php/ekomaks

pengembangan produk diutamakan untuk produk gula semut sehingga mendapatkan dukungan dari KOMPAK dalam menerapkan standar operasional prosedur ketika melakukan produksi dan sertifikasi produknya.

Perubahan kemasan juga dilakukan setelah melalui berbagai pertimbangan untuk memperluas akses pasar seperti merubah ukuran kemasan produk gula semut. Variasi kemasan produk juga dibedakan mulai dari paket kemasan ekonomis sampai kemasan yang besar. Selanjutnya fasilitasi Kompak dan Dinas Koperasi dan Usaha Mikro Kabupaten Pacitan adalah menghubungkan pasar dengan keperantaraan pasar yaitu mempertemukan dengan offtaker atau perusahaan yang mau membeli dan memasarkan produk gula semut sekaligus memberikan pendampingan dalam aspek dampak sosialnya. Hal tersebut dilakukan untuk memberikan rasa percaya diri yang lebih kepada umkm pelaku gula kelapa bahwa produk yang mereka hasilkan dapat diterima pasar dan juga memastikan serta memperluas pemasaran dari produk gula semut. Permasalahan lainnya yang juga menjadi perhatian adalah manajmen bisnis meliputi peningkatan pengetahuan tentang pengelolaan laporan keuangan

Dengan prioritas pada produk gula semut terjadi beberapa perubahan seperti peningkatan jumlah pembuat gula semut yang semula hanya memproduksi gula cetak. Tetapi kapasitas gula cetak dan gula semut mengalami peningkatan produksi. Dari sebelumnya rata-rata yang dihasilkan untuk gula cetak sebesar $59 \mathrm{~kg}$ dan gula semut sebanyak $30 \mathrm{~kg}$. Namun kenaikan yang terjadi yaitu gula cetak $120 \mathrm{~kg}$ dan gula semut $250 \mathrm{~kg}$. Bertambahnya produksi gula semut disebabkan juga karena meningkatkan jumlah pembuat gula semut dari para anggota koperasi itu dari semula 1 orang menjadi 6 orang. Pada dasarnya pada tahap awal di tahun pertama memang belum kelihatan secara signifikan bagaimana trend yang terjadi setelah terjadinya sinergitas tersebut akan tetapi yang terlihat adalah bagaimana proses implementasi sinergitas sudah dimulai dari fokus peningkatan kualitas produk melalui berbagai strategi yang juga mendapatkan bantuan serta perhatian dari berbagai pihak baik itu BUM desa, pemerintah dan kompak.

\section{KESIMPULAN DAN SARAN}

\section{A. Kesimpulan}

Pada kenyataannya telah terjalin sinergitas antara koperasi Himpulo dan BUM desa Rejo Raharjo untuk pengembangan gula kelapa yang merupakan produk unggulan Desa Kalak Kecamatan Donorojo. Sinergitas tersebut dikuatkan melalui perjanjian kerjasama membangun bisnis bersama untuk produk gula kelapa meliputi yaitu gula cetak dan gula semut. Gula semut menjadi prioritas pengembangan karena lebih memiliki nilai ekonomi yang tinggi yaitu harga jualnya lebih tinggi daripada gula cetak. Skema yang dilakukan dalam sinergitas tersebut adalah penyertaan modal untuk menguatkan bisnis gula kelapa dan keuntungannya didasarkan pada prosentase bagi hasil yang telah disepakati. Sesuai dengan perjanjian kerjasama nilai penyertaan modal kepada koperasi himpulo adalah sebesar Rp. 5.000.000.

Pada tahap awal sinergitas memang tidak kelihatan proses bisnis berjalan sebab BUM desa Rejo Raharjo belum memberikan modal penyertaannya kepada Koperasi Himpulo. Sebab pada tahap ini lebih fokus pada peningkatan produk yaitu dari aspek mutu produk, merek, pemasaran dan manajemen bisnis. Himpulo dan Rejo raharjo bersama-sama menyusun strategi pengembangan usaha untuk mencapai tujuan yang diinginkan. Karena harapannya adalah meningkatkan pendapatan dan kapasitas usaha menjadi semakin besar. Dalam proses ini sebenarnya juga mereka membutuhan peran pendampingan dan pelatihan dari berbagai pihak baik itu pemerintah dan KOMPAK sebagai lembaga pemberdayaan masyarakat.

\section{B. Saran}

Untuk melihat perkembangan kemajuan sinergitas koperasi Himpulo dan BUM Desa Rejo Raharjo melalui trend peningkatan keuntungan atau pendapatan dan kapasitas produksi dapat dilakukan setelah 3 tahun berjalan sehingga bisa mengukur keberhasilannya.

\section{VI.DAFTAR PUSTAKA}

Kuswarno, E. 2009. Metodologi Penelitian Komunikasi Fenomenologi, Konsepsi, Pedoman dan Contoh Penelitiannya. Bandung: Widya Padjajaran. Hendar. 2010. Managemen Perusahaan Koperasi, Pokok Pokok Pikiran Mengenai Managemen dan Kewirausahaan Koperasi. Jakarta: Gelora Aksara Pratama Limbong Betrnhard. 2010. Pengusaha Koperasi, Jakarta; Rafi Maju Mandiri

Moleong J.Lexy. 2005. Metodologi Penelitian Kualitatif. Bandung: Remaja Rosdakarya

Pachta Andjar. W, dkk. 2008. Hukum Koperasi di Indonesia. Jakarta: Fajar Interpratama Offset

Sugiono. 2010:Metode Penelitian Kuantitatif Kualitatifdan R\&B, Bandung, Alfabeta

Permendesa PDTT No 4 Tahun 2015 tentang Pendirian, Pengurusan Dan Pengelolaan, Dan Pembubaran Badan Usaha Milik Desa

Undang-Undang No. 25 tahun 1992 tentang perkoperasian

MOU antara Kementrian Desa, Pembangunan Daerah Tertinggal dan Transmigrasi Republik Indonesia dengan Kementrian Koperasi dan Usaha Kecil dan Menengah Republik Indonesia Tentang Pembangunan dan Pemberdayaan Ekonomi Masyarakat Desa, Daerah Tertinggal dan Transmigrasi Melalui Sinergi Koperasi dan Badan Usaha Milik Desa No : 12 /M.DPDTT/KB/IX/2016 dan No : 14 /KB/M.KUKM/IX/2016

Undang-Undang No 6 tahun 2014 tentang Desa 